\title{
Analysis of communicative methods effectiveness in teaching foreign languages during the coronavirus epidemic: distance format
}

\author{
Ekaterina A. Samorodova - Irina G. Belyaeva - Sofia A. Bakaeva
}

DOI: 10.18355/XL.2021.14.01.11

\begin{abstract}
The forced transition to distance learning in 2020 forced the world scientific community to pay special attention to researching the effectiveness of the methodology for teaching subject disciplines in a remote format. In this manuscript, the authors did attempt to study, analyze, and classify various methods of teaching a foreign language (English, French, and German) at MGIMO University. The present research is based not only on a direct professional experience of working at a distance but also on an anonymous survey conducted among students. The purpose of this study is to develop and describe the most effective model of teaching a foreign language in the specified conditions. In addition to the empirical approach observation of students' work during the semester, the use of experimental control methods, comparison, comparative analysis of the results - the authors also use data from an anonymous survey among students and foreign language teachers, which emphasizes the practical significance and relevance of the study. During the students questioning, it was found out which teaching methods and specific exercises are the most effective in the framework of a distance lesson. The questioning of teachers made it possible to classify statistical results and identify methods that teachers use in teaching a foreign language in a distance format and which could be used by them but are not used. On the basis of the data obtained, the authors conclude that there is a discrepancy between the ideas of teachers and students about the effectiveness of using certain forms of online education. This conclusion will allow in the near future to adjust the methodological and teaching aids for working in a distance format in foreign language classes.
\end{abstract}

Key words: pandemic, coronavirus, distance learning, distance learning, foreign language teaching, teaching methods

\section{Introduction}

Distance learning has been known as a form of education for nearly three hundred years. Originated in Boston, it made it possible for everyone to complete the Boston shorthand and accounting courses without coming to this city. Students received educational materials by mail for self-study. The so-called mail-order training or correspondence training has existed for several centuries. In Russia, correspondence or distance education was based on the principle of such correspondence education. It didn't disappear with the e-mail advent, and it only accelerated the process of receiving and sending educational materials. Distance learning began to undergo fundamental changes with the emergence of new technical capabilities that allow teachers and students to communicate at a distance and the emergence of electronic learning platforms. Participants in distance learning began to actively use new technical opportunities to bring distance learning as close as possible to full-time in order to improve its quality. The development of distance learning forms is carried out with the involvement of administrative, technical, and pedagogical resources. The administration sets hours for the development of relevant professional competencies, and teachers develop educational materials that develop the relevant professional skills, technical services implement the developments of the administration and teachers in electronic format. The content of training, depending on the specialization

XLinguae, Volume 14 Issue 1, January 2021, ISSN 1337-8384, eISSN 2453-711X 
and focus, in each university is individual; this is the reason for the development of each university of its own electronic platforms for distance learning. The first step that was undertaken by higher educational institutions that train specialists on a full-time basis was the translation of educational materials into electronic format. This opened up access for students, located anywhere in the world, to the educational materials of the university in which they study. Educational materials, converted into electronic form, began to grow overgrown with interactive exercises. A radical change in the socalled correspondence learning brought with it the ability to contact the teacher with his students online. Distance learning in terms of efficiency began to approach fulltime education. The most important stage in the development of distance learning was the criteria and methods for assessing students. If, in the course of correspondence education, universities were forced to take exams in full-time format, now, thanks to the video control system, it is possible to assess the quality of knowledge remotely (in distance).

Foreign language training of higher educational institutions students in the correspondence format has undergone significant changes. The share of classical mnemonic techniques for memorizing educational material, based on its visualization, has increased. With the help of computer graphics, almost any element of information can be transformed into a visual image and an artificial association in order to connect images, thus facilitating the process of capturing. Graphically expressed sequences of associations ensure their rother firm fixation in memory. Memorizing a number of new words can be carried out by creating a graphic drawing with a single storyline, separate graphic pictures united by a single storyline, as well as images that do not form a single semantic whole. Foreign language training does not mean memorizing the sequence of words as such, but their nomination in a foreign language. Such a correlation can be realized purely graphically or in combination with dubbing foreign words. That is, the introduction of new vocabulary can be represented by a picture that combines the meaning of words for memorization with graphic signatures; a film that combines graphics and audio within the framework of the studied vocabulary, a number of pictures connected by meaning with the graphic signatures of the studied lexemes, only with their dubbing, or a combination of graphics and audio.

Students were given the opportunity to independently train hard skills until they are fully automated, which is necessary when working on vocabulary and grammar.

Online consultations, lectures, and reports in an active form, seminars, various types of group forms of education, made possible by participating in forums, chats, online conferences, have become new opportunities for the distance learning format, developing both rigid and flexible skills.

The 2020 pandemic has made significant adjustments to all forms of university education. Full-time education has become unavailable for students of most universities in the world due to the imposed bans and restrictions at the state level in order to reduce the victims of the pandemic. Students of correspondence faculties found themselves in the most advantageous situation, since learning at a distance did not become a force majeure for them, university teachers and students possessed the necessary arsenal of equipping the pedagogical process both from a technical point of view and from a methodological point of view for conducting classes in a remote mode. Thus, distance learning has become the main form of education for a long time. The work experience of MGIMO (Russia), in which the only form of education is full-time, during the Pandemic showed that the methods and principles of traditional full-time education became the basis for teaching in distance mode, and the main task was to bring distance education as close as possible to full-time education with the help of modern technical equipment. Going beyond traditional teaching methods and creating our own methods within distance education could improve the quality of distance learning. To develop new methods of teaching in a distance mode, it is 
necessary to first analyze the existing experience of distance teaching and find out how the methods of full-time learning in a distance format function.

All types of educational activities in electronic mode can be divided into four groups:

- webinars

- online conferences

- forums,

- $\quad$ simulators and tests.

Webinars and online conferences allow you to organize lectures by invited teachers in a foreign language, discussions, round tables, educational games with peers and native speakers, and work within a training company.

Forums are an opportunity for joint brainstorming, developing skills of various types of writing. Simulators allow you to consolidate and expand knowledge in the studied discipline. Tests provide control of students' knowledge, partially relieving the burden on teachers, freeing them from checking exercise books. As teachers, a natural question arose before us: what methods of full-time teaching of a foreign language are used and can be applied within the framework of the above four conditionally distinguished forms of activity in a distance format, which of them are the most effective for optimizing the process of mastering foreign languages from the point of view of students

In order to answer these questions, we formulated the following research objectives:

1) Identification of methods of full-time teaching of foreign languages in nonlinguistic universities, which are applied and can be applied in a distance format.

2) Evaluation of the effectiveness of these methods from the point of view of students.

\section{Literature review}

The authors analyzed the scientific works of Russian and foreign teachers, in which various methods of teaching foreign languages were identified and analyzed. As a result of the analysis of scientific literature, the following methods were identified that are widely used in teaching a foreign language in modern pedagogical practice: project (Nargis, Armelif, 2018), case study (Fesenko, Fedyaeva, Bestsennaya, 2017), ICT (Fedotova,2015, Bilyalova, 2017, Mazur, Rzepka, Araki, 2018), game (Nechayuk, 2017, Kalyuzhnaya, Skorobogatova, Vlasova, 2015, Prikoszovits, 2017), tandem (Pomino, Salom, 2016), extensive reading (Renandya, Jacobs, 2016) podcasts (Masudul, Tan, 2013), associative (Vasyuhnevich, 2016), cooperative learning, collaborative learning (Mikhina,Potrikeyeva, 2018), sliding (Antselevich, Smagrinskaya, Malakhov, 2015), contrastive linguistics (Durst, 2017), discussions (Yelon, Cooper, 1984), dilemma (Kholod, 2019), Jigsaw Reading (Yahananiky, 2018), theatrical performance (Raquel, 2011), SCRUM (Jurado-Navas, Munoz-Luna, 2017 ), round table (Rodomanchenko, 2017), Peer review (Sysoev, Merzlyakov, 2016), mnemonics (Ostrikova, Zheltukhina, Zyubina, Sidorova, 2018), brainstorming (Gogus, 2012), video blogging method, grammar and translation (Thamarana, 2015), interview, briefing, audio-lingual method (Bidenkob, Shcherbak 2017), flipped learning / flipped classroom (Jun Wang, Clare Wright, 2018), CLIL-subject-language integrated learning (Xabier San Isidro, 2018) cooperative teaching method (Wysocki, 2010).

All identified methods of teaching a foreign language at a non-linguistic university can be grouped as follows (Table 1):

XLinguae, Volume 14 Issue 1, January 2021, ISSN 1337-8384, eISSN 2453-711X 
Table 1.

\begin{tabular}{|l|l|}
\hline 1 & ICT \\
\hline 2 & collaborative learning \\
\hline 2.1 & project \\
\hline 2.2 & jigsaw reading \\
\hline 2.3 & SCRUM \\
\hline 2.4 & cooperative learning \\
\hline 3 & problems method \\
\hline 3.1 & discussions \\
\hline 3.2 & dilemma \\
\hline 3.3 & case-study \\
\hline 3.4 & round table \\
\hline 3.5 & peer review \\
\hline 4 & game \\
\hline 4.1 & role game \\
\hline 4.2 & business game \\
\hline 4.3 & training firm \\
\hline 5 & tandem \\
\hline 6 & mnemonics \\
\hline 7 & extensive reading \\
\hline 8 & brainstorming \\
\hline 9 & flipped classroom \\
\hline 10 & CLIL \\
\hline
\end{tabular}

\section{Materials and methods}

This study is based on the analysis of scientific works of Russian and foreign scientists covering the problem of teaching foreign languages in non-linguistic universities, the results of the questionnaire survey of foreign language teachers at MGIMO, and the results of the survey of students of the 1st, 2nd, 3rd and 4th-year undergraduate courses studying a foreign language in such spheres like international relations, political science, law, economics, and journalism.

The solution to the first research question involves identifying the methods that teachers use when teaching a foreign language in a distance format and which could be applied by them but are not used. For this, an anonymous questionnaire was distributed to teachers, the task of which was to identify the methods of teaching a foreign language that they use, as well as methods of teaching a foreign language that corresponds to the distance format but is not used by teachers. The survey was attended by 50 teachers of the departments of English, French and German languages, who were asked to choose from Table 1 the methods that they used in distance 
learning. The method using ICT was accordingly excluded since it is the basis for all types of learning activities in distance learning.

To solve the second research question, that is, to identify the degree of effectiveness of a particular method of teaching in a distance format, a survey of students was conducted. The questionnaire consisted of two parts. In the first part of the questionnaire, students were asked to answer the following questions:

- Did distance learning take more time to complete foreign language assignments than during full-time?

- Do you think that in order to successfully study foreign languages in a distance format, a student should put more effort than full-time?

- Do you find it useful for yourself personally that the assignments had to be typed rather than written by hand?

- Do you feel a lack of emotional interaction with the teacher during distance learning?

- What form of work in a distance format when learning foreign languages seems most effective for you personally:

(Regular video seminars and regular implementation of written homework / Lack of video seminars, independent review of material and submission of work before the deadline)

- What technical combination of distance learning lessons is preferable for you in terms of psychological comfort?

- Audio only, video disabled

- Mandatory video and audio

- Communication only in writing

- Would you choose distance learning instead of regular classes?

These questions make it possible to understand how comfortable the distance format is for students.

In the second part, students are invited to select and evaluate the methods of teaching a foreign language that was used by their teachers in a distance format. For this, from the methods listed in Table 1 (the method using information and communication technologies, respectively, was not proposed), the methods of teaching a foreign language in higher educational institutions that were relevant in the opinion of the authors were selected, which formed the basis for the survey of undergraduate students. The assessment was made on a scale from 5 points to 0 points, where:

5 - a method of very high importance;

4 - a method of high importance;

3 - method of average significance;

2 - a method of low significance;

1- method of very low importance;

0 - method of no significance.

Several methods could have been given the same number of points.

Methods that were not applied in your training were not subject to evaluation.

To solve the problems posed in this article, methods were used that were applied at the empirical level (study and analysis of the works of Russian and foreign scientists, teachers on the research questions posed in the work; student survey in the form of a questionnaire) and at the theoretical level - analysis, synthesis, comparison, generalization, deduction, and induction.

\section{Research results}

The survey revealed the methods and their frequency that were used by MGIMO teachers when working with students in a distance format in the context of the coronavirus pandemic (Figure 1):

XLinguae, Volume 14 Issue 1, January 2021, ISSN 1337-8384, eISSN 2453-711X 


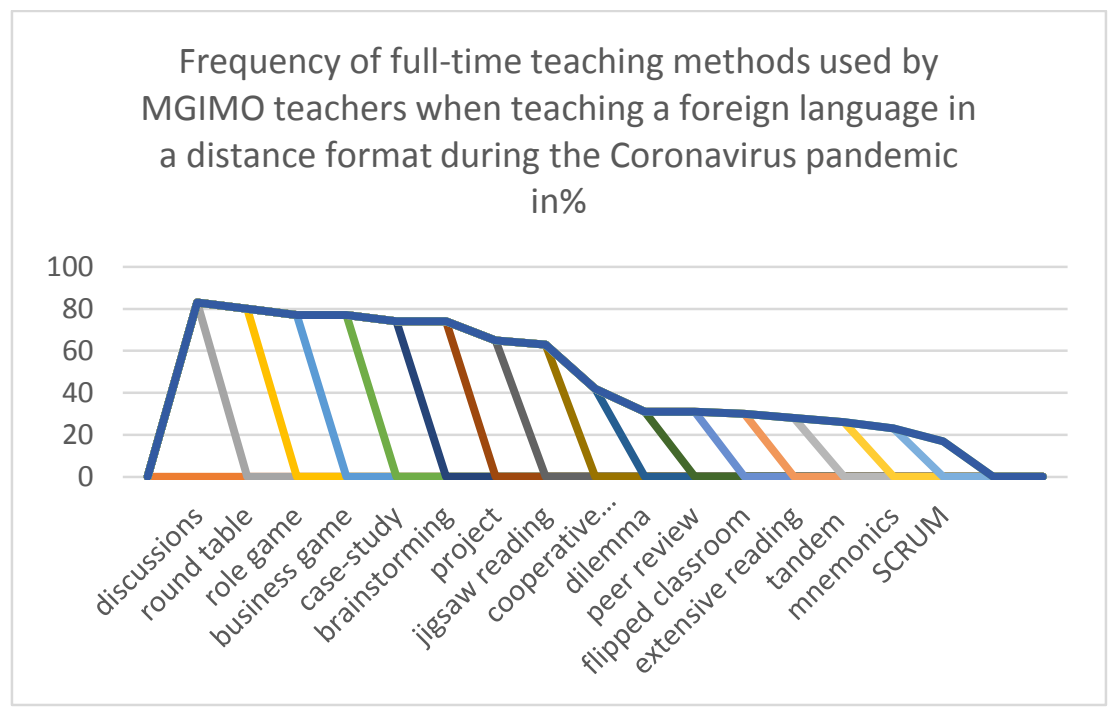

Figure 1.

The diagram clearly shows that when distance teaching students a foreign language at MGIMO, teachers used almost all the methods that they used during face-to-face studies. This has become possible thanks to modern technological means that blur the line between face-to-face and distance learning thanks to the possibility of audiovisual contact. The most popular method of teaching a foreign language has become a discussion. SCRUM was used less often, just as one of the methods of training speech skills.

The students' questionnaire allows us to find out what types of activities in learning a foreign language in distance mode caused the greatest difficulties and which of the methods of full-time education used is most effective in the conditions of distance learning in a foreign language.

Of course, as we assumed, with distance learning, there is no emotional interaction between the teacher and the student, which most students consider as a significant disadvantage of this form of education. Nevertheless, $58 \%$ of students prefer teaching with the "video" function turned off. The main problem in distance learning in a foreign language for $99 \%$ of students was technical problems. Therefore, $75 \%$ of students would choose the distance format only if it was impossible to personally attend the class. According to $92 \%$ of students, distance learning of foreign languages is based on video seminars, and regular written work. Distance students spent as much time on homework as full-time students. But nevertheless, most of them had to put more effort into distance learning than during their studies directly within the walls of the university. We did not receive a definite answer about the advantages of typing homework assignments and handwriting. The opinions were equally divided. Half of the students consider the ability to enter text on a computer to be an advantage, the other a disadvantage.

The second part of the questionnaire forms an idea of teachers of foreign languages about the effectiveness of their methods of full-time education in distance learning. The data from this survey are displayed in Figure \# 2. 


\section{Evaluation of the effectiveness of face-to-face methods in a distance learning format from the point of view of students in\%}

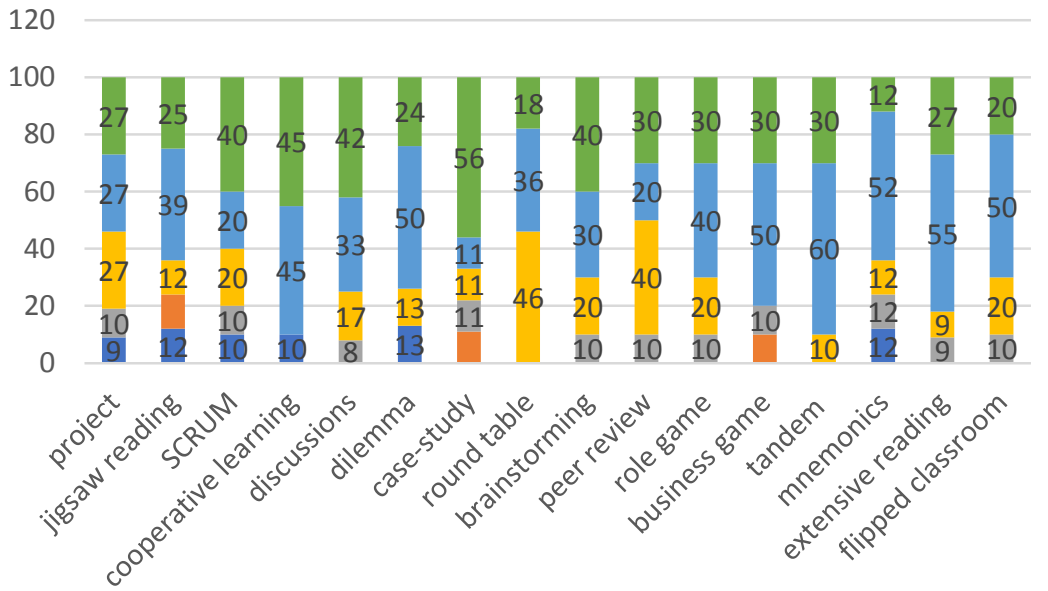

Figure 2.

According to the students' assessment, the most effective method for distance learning is a case study, which is in fourth place in terms of frequency of use in foreign language classes after discussion, round table, role-playing, and business games. According to students, the most ineffective method of distance learning is a dilemma, which, in terms of the frequency of use by teachers in distance learning, occupies a central position. On the other hand, $50 \%$ of students rated the effectiveness of this method at four, which justifies its rather frequent use in foreign language classes in a distance format. Efficiency in remote conditions by 4 points. Most of the students assessed the tandem method, which was used to work in the Zoom system using the "waiting room" function. This method was used extremely rarely by teachers in distance learning.

\section{Discussion and conclusions}

The results of this study revealed a discrepancy in the ideas of teachers and students about the effectiveness of the use of full-time forms of training in a distance format, which allows you to adjust the methodological and teaching aids for working in a distance format in foreign language classes. On the one hand, the advantage of distance learning is its flexibility, and the transfer of classroom lessons to the online format helps to save a student's time resource. But, on the other hand, the training time for a teacher increases significantly: methodological design becomes more complicated, the choice of control forms and their design, as well as work with the plan, materials, and presentations, becomes more painstaking and voluminous. The "experimental" period of work at a distance showed that the teachers based the lessonless presentation of material on discussion forms of work since, at first glance, it is the various types of oral activity that seem to be the most effective at a distance. However, it is impossible to exclude written types of work on grammar and

XLinguae, Volume 14 Issue 1, January 2021, ISSN 1337-8384, eISSN 2453-711X 
vocabulary from foreign language teaching programs - therefore, it is necessary to find a suitable interactive format that allows for the most effective practice (homework) and control of the acquired competencies. The analysis of the assessment by students and teachers of various methods of teaching a foreign language carried out in this study makes it possible to choose the most effective exercises, tasks, and work format when building a plan. In other words, it is necessary to strive for maximum compensation for the advantages of full-time teaching, because the most unfavorable scenario for the development of events, in the opinion of many specialists, is not the transition from classroom teaching to distance teaching, but the widespread replacement of distance learning by correspondence, which will lead to a guaranteed decrease in the quality of education. Undoubtedly, distance learning is an effective additional form of full-time education, but only distance learning is not yet the unambiguously preferred form of teaching foreign languages at MGIMO. First of all, due to the lack of opportunities for the uninterrupted operation of technology, as well as its impossibility in the psychological and emotional plans to replace a human.

\section{Bibliographic references}

ANTSELEVICH O. - SMAGRINSKAYA N. - MALAKHOV B. 2015. Modern educational technologies in non-linguistic universityll Scientific enquiry in the contemporary world: theoretical basics and innovative approach research articles. vol. 2, PEdagogic and psychology. DOI: 10.15350/L_26/4_2ISBN-10:194165519X ISBN13:978-1-941655-19-1 DOI: 10.15350/L_26/4_2

BIDENKOB, L. - SHCHERBAK, H. 2017. Implementing audio-lingual method to teaching Ukrainian as a foreign language at the initial stage. Advanced Education. 3. pp. 23-27. 10.20535/2410-8286.82711. ISSN 2410-8286 (Online), ISSN 2409-3351 (Print)

BILYALOVA, A. 2017. ICT in Teaching a Foreign Language in High School. Procedia - Social and Behavioral Sciences. vol. 237, pp. 175-181. 10.1016/j.sbspro.2017.02.060. DOI: 10.1016/j.sbspro.2017.02.060 ISSN: 1877-0428

DURST, U. 2017. Tekin, Özlem: Grundlagen der Kontrastiven Linguistik in Theorie und Praxis. Informationen Deutsch als Fremdsprache, vol. 41, n. 2, 3, pp. 384-386. doi:10.1515/infodaf-2014-2-385

FEDOTOVA, N.L. 2015. On the concept of distance training course „, Methods of teaching Russian as a foreign language (RFL): traditions and innovations "". Russian Linguistic Bulletin. vol. 4, n. 4, 41 p. OI: https://dx.doi.org/10.18454/RULB.4.05 ISSN 2411-2968(ONLINE), ISSN 2313-0288 (PRINT

FESENKO, O.P. - FEDYAEVA, E.V. - BESTSENNAYA, V.V. 2017. Cases in methods of teaching russian as a foreign language // Language and Culture. n. 9, pp. 104-117. DOI: 10.17223/24109266/9/12 ISSN 2410-9266

GOGUS, A. 2012. Brainstorming and Learning. In: Seel N.M. (eds) Encyclopedia of the Sciences of Learning. Springer, Boston, MA. https://doi.org/10.1007/978-1-44191428-6_491 print ISBN978-1-4419-1427-9 Online ISBN978-1-4419-1428-6

JUN WANG, NA. AN. - CLARE, WRIGHT 2018. Enhancing beginner learners' oral proficiency in a flipped Chinese foreign language classroom, Computer Assisted Language Learning, vol. 31, n. 5, 6, pp. 490-521, DOI: 10.1080/09588221.2017.1417872

JURADO-NAVAS, A. - MUNOZ-LUNA, R. 2017. Scrum Methodology in Higher Education: Innovation in Teaching, Learning and Assessment. International Journal of Higher Education, vol. 6, n. 6, pp. 1-18 2017. DOI: https://doi.org/10.5430/ijhe.v6n6p1

KALYUZHNAYA, T.V. - SKOROBOGATOVA, E.V. - VLASOVA, A.V. 2015. Business role-play as a means of competence approach implementation in teaching the English language at higher education institutions. Bulletin of Kemerovo State 
University. vol. 3, n. 2, pp. 52-54. (In Russ.) https://doi.org/10.21603/2078-89752015-2-52-54

KHOLOD, N.I. 2018. Application of moral dilemmas method for students communicative competence development in classes of foreign language at higher education institution, ВестникТГПУ. n. 7, (196). Available online: https://cyberleninka.ru/article/n/primenenie-metoda-moralnyh-dilemm-dlya-razvitiyakommunikativnoy-kompetentsii-studentov-na-zanyatiyah-po-ino-strannomu-yazykuv-vuze

KRALOVA, K. - STIPEK, J. - VONKOVA, H. - PAPAJOANU, O. 2020. Selfassessment of motivation for information and communication technologies learning: Results of a pilot study among secondary school students. In Slavonic Pedagogical Studies Journal, 2020, vol.9 N.1 pp. 70-77. ISSN 1339-8660.

MASUDUL HASAN, Md - TAN, B. H. 2013. Podcast Applications in Language Learning: A Review of Recent Studies. English Language Teaching. 6. 10.5539/elt.v6n2p128.

MAZUR M. - RZEPKA R. - ARAKI K. 2018. Teaching Words in Context: CodeSwitching Method for English and Japanese Vocabulary Acquisition Systems. In: Vetulani Z., Mariani J., Kubis M. (eds) Human Language Technology. Challenges for Computer Science and Linguistics. LTC 2015. Lecture Notes in Computer Science, vol 10930. Springer, Cham DOI https://doi.org/10.1007/978-3-319-93782-3_24

MIKHINA, O. V. - POTRIKEYEVA, E. S. 2018. On the way of the search of new methods in teaching foreign languages (analysis of domestic and foreign experience). Perspektivy naukii obrazovania -Perspectives of Science and Education, vol. 36, n. 6, pp. 155-163. doi: 10.32744/pse.2018.6.17. (In Russ., abstr. in Engl.)

NARGIS, N. - ARMELIA, L. 2018. Optimizing EFL learners' communicative competence through short movie project// Asian EFL Journal. vol. 20, pp.201-208. ISSN: $1738-1460$

NECHAYUK, I.A. 2017. Active methods as optimization model for teaching English for special purposes. Interactive science, vol. 2, n. 12, pp. 96-99. doi:10.21661/r117837

NOVIKOVA, I.A. - BERISHA, N.S. - NOVIKOV, A.L. - SHLYAKHTA, D.A. 2020. Personality Traits and Foreign Language Proficiency in Russian Linguistics and Non-Linguistics Students. RUDN Journal of Psychology and Pedagogics. vol. 17 (3). pp. 426-439. ISSN 2313-1705 doi: 10.22363/2313-1683-2020-17-3-426-439

OSTRIKOVA, G.N. - ZHELTUKHINA, M.R. - ZYUBINA, I.A. - SIDOROVA, I.G. 2018. Learning Via Visualization at the Present Stage of Teaching a Foreign Language. Astra Salvensis, vol. VI, n. 1, pp. 601-607.

POMINO, J. - SALOM, D. 2016. Integrating E-tandem in Higher Education. Procedia - Social and Behavioral Sciences. vol. 228. pp. 668-673. 10.1016/j.sbspro.2016.07.102.

PRIKOSZOVITS, M. 2017. Auf dem Prüfstand - Wie berufsbezogen und praktikabel sind moderne handlungsorientierte DaF-Unterrichtsaktivitäten? In: Magazin 25/2017 (Andalusischer Germanistenverband), pp. 34-45. DOI: http://dx.doi.org/10.12795/magazin.2017.i25.04

RAQUEL, M. 2011. Theatre production as a language learning environment for Chinese students. Journal of Drama and Theatre Education-Asia. 2. 93-120.

RENANDYA, W.A. - JACOBS, G.M. 2016. Extensive Reading and Listening in the L2 Classroom. In: Renandya W., Widodo H. (eds) English Language Teaching Today. English Language Education, vol 5. Springer, Cham. https://doi.org/10.1007/978-3-319-38834-2_8

RODOMANCHENKO, A. 2017. Roundtable Discussion in Language Teaching: Assessing Subject Knowledge and Language Skills. Journal of Language and Education, vol. 3, n. 4, pp. 44-51. https://doi.org/10.17323/2411-7390-2017-3-4-44-51

XLinguae, Volume 14 Issue 1, January 2021, ISSN 1337-8384, eISSN 2453-711X 
SAN ISIDRO, X. 2018. Innovations and Challenges in CLIL Implementation in Europe, Theory Into Practice, vol. 57, n. 3, pp. 185-195, DOI: 10.1080/00405841.2018.1484038

SYSOYEV, P.V. - MERZLYAKOV, K.A. 2016. Methods of teaching international relations students writing skills using peer review/ P. V. Sysoyev,K. A. Merzlyakov// YazykiKultura-Language and Culture. vol. 2, n. 3, 4, pp.195-206. DOI: 10.17223/19996195/34/15.

THAMARANA, S. 2015. A Comparative Study of Various English Language Teaching Methods, Approaches. 10.13140/RG.2.1.4026.5046, DOI: 10.13140/RG.2.1.4026.5046

VASYUHNEVICH, I.A. 2016. The associative approach in the study ofLatin medical and pharmaceutical terminology. Science Almanac. vol. 71(21). DOI:10.17117/na.2016.07.01.216

WYSOCKI, K. 2010. Kooperatives Lernen im Englischunterricht: die Kommunikationsfähigkeit aktiv fördern - vom ersten Schuljahr an / Karolina Wysocki. Mit einem Vorw. von Ruth Kirchmann. Essen: Neue-Dt.-Schule-Verl.-Ges., $175 \mathrm{p}$.

YUHANANIKY, Y. 2018. Using jigsaw model to improve reading comprehension of the ninth graders of SMPN 1 Karangploso. IJOTL-TL: Indonesian Journal of Language Teaching and Linguistics. vol. 3, n. 1, pp. 51-64. DOI: https://doi.org/10.30957/ijoltl.v3i1.50.

YELON, S.L. - COOPER, C.R. 1984. Discussion: A naturalistic study of a teaching method. Instr Sci, vol. 13, pp. 213-224. https://doi.org/10.1007/BF00055532

Words: 4216

Characters: 29363 (16,31 standard pages)

Assoc. Prof. Ekaterina A. Samorodova, PhD.

French Language Department

Moscow State Institute of International Relations (MGIMO University)

119454, Moscow, Prospekt Vernadskogo, 76

Russia

ORCID : https ://orcid.org/0000-0002-0702-0253

samorodova.ekaterina.78@mail.ru

Irina G. Belyaeva, PhD.

German Language Department

Moscow State Institute of International Relations (MGIMO University)

119454, Moscow, Prospekt Vernadskogo, 76

Russia

ORCID : https ://orcid.org/0000-0002-7083-3564

irinatimakova@mail.ru

Sofia A. Bakaeva PhD.

French Language Department

Moscow State Institute of International Relations (MGIMO University)

119454, Moscow, Prospekt Vernadskogo, 76

Russia

ORCID https://orcid.org/0000-0001-8196-0350

sophiebakaeva@gmail.com 